\section{JOB SATISFACTION OF MEN AND WOMEN EMPLOYED IN MANUFACTURING SECTOR AND EDUCATION IN SERBIA}

\author{
Jelena Vukonjanski ${ }^{1}$, Edit Terek ${ }^{1,{ }^{*}}$, Bojana Gligorović ${ }^{1}$ \\ ${ }^{1}$ University of Novi Sad, Technical Faculty "Mihajlo Pupin" \\ Đure Đakovića Street, Zrenjanin, Serbia
}

\begin{abstract}
:
This paper presents the results of the research on job satisfaction of men and women employed in manufacturing sector and in education sectors in Serbia. The surveys were conducted in Serbian enterprises, as well as in Serbian primary schools. In the first survey, the data were obtained by questioning N1=256 middle managers, from 131 companies in Serbia. The sample comprised 136 men and 120 women. In the second survey, the data were obtained by questioning N2=362 teachers, from 57 primary schools in Serbia. The sample included 250 women and 112 men. T-test was used for statistical analysis. Specifically, three t-tests were used for the following groups of data: job satisfaction in industrial sector and job satisfaction in education; job satisfaction of men in manufacturing sector and job satisfaction of women in manufacturing sector; job satisfaction of men in education and job satisfaction of women in education. The main conclusions are as follows: employee job satisfaction is higher in education than in industrial sector; job satisfaction in industrial sector is higher for men than for women; job satisfaction in education is slightly higher for women than for men.
\end{abstract}

\section{Key words:}

job satisfaction, men and women, companies in Serbia, primary schools in Serbia.

\section{INTRODUCTION}

Job satisfaction is one of the most widely studied phenomena in organizational behaviour literature. Since 1972, over 3000 studies, that examine the impact and consequences of job satisfaction, have been published (Locke, 1976). In addition, there is no indication that the interest in researching job satisfaction has been reducing in the last 35 years. Spector (1997) suggests that job satisfaction is, without a doubt, the most studied variable in I/O Psychology (Industrial and Organizational Psychology). He also states that job satisfaction is the central variable in many theories dealing with the phenomenon of organization, such as the nature of work, supervision and work environment. Numerous studies show the correlation between job satisfaction and variables such as organizational commitment, absenteeism, work motivation and organizational culture (Meyer et al., 2002; Sempane et al., 2002; Scott and Taylor, 1985; Martin and Miller, 1986; Locke and Latham, 1990). 
Individuals evaluate their jobs on the basis of factors which they regard as being important to them (Sempane et al., 2002). This evaluation is an emotional response to the work, which can vary along a continuum from positive to negative (McCormick and Ilgen, 1985). People are satisfied with their jobs when they feel good about their work. That feeling is often associated with their sense of doing a good job, becoming more skilled in their profession and having a good performance (Megginson et al., 1982).

In this paper, job satisfaction is viewed as an attitude towards work as a whole (of a global satisfaction) or to certain aspects. Satisfaction with specific aspects usually refers to several aspects, including the work, supervision, pay, opportunities for advancement and associates. Due to the multidimensionality of job satisfaction / dissatisfaction, many authors choose to measure individual dimensions of job satisfaction rather than overall job satisfaction (Vukonjanski et al., 2012). Individual dimensions of job satisfaction enable the researcher to identify the relationship between individual dimensions of job satisfaction and various internal and external values.

Job satisfaction is one of the predictors of many significant organizational outcomes, including job performance (Judge et al., 2001). This research revealed a number of conclusions on the relationship between satisfaction in the workplace and productivity. Also, it has been shown that factors, related to organizational culture and personal determinants, have the greatest impact. According to Bellou (2010), employees recognize fairness, opportunities for personal growth, enthusiasm for the job and a good reputation as amplifiers of job satisfaction, while aggression is seen as a cultural trait that decreases job satisfaction. Research conducted by Lee and Chang (2008), among Chinese (Taiwan) workers, confirms the strong relationship between organizational culture and job satisfaction. Similarly, Fargher et al. (2008) investigated the relationship between organizational culture and job satisfaction in Eastern and Western Europe. The study points to the strong influence of national culture on individual attitude toward job satisfaction. There are significant differences between employees in Eastern and Western Europe, which are primarily due to different meaning and influences of family and religion in these two regions.

As job satisfaction is very important for the functioning of the companies, and it also has a great significance for the functioning of education- al institutions, where the satisfaction of teachers is most widely observed. According to Shann (1998), the job satisfaction of teachers is very important, influencing factor of teachers' commitment and performance and their retention in the profession. Therefore, the job satisfaction of teachers potentially contributes to the overall effectiveness of the school. In reference (Hoerr, 2013), it is pointed to the importance of job satisfaction of teachers for success in the classroom and the overall atmosphere in the school. Hoerr further states that the growth of teachers' job satisfaction develops through the teaching and promotion of teachers. They become more effective, and therefore happier. According to Wolk (2008), the overall satisfaction and satisfaction of students in the school can hardly be realized without teachers who are satisfied with their work. Teachers' job satisfaction is very modern field of research and new questionnaires for measuring the job satisfaction of teachers have been developed (Ho and $\mathrm{Au}, 2006$ ). Finally, according to Fraser and Hodge (2000), job satisfaction has a central role in studies relating to work and occupation.

The issue of job satisfaction is very sensitive in Serbia, both in manufacturing sector and in education. Employees in industrial sector often have reduced job satisfaction, due to the large volume of work, longer working hours and low salaries. Teachers are often frustrated by low incomes, relatively poor working conditions and the fact the profession of teachers is not valued enough. So, in manufacturing sector and education there are reasons why employees have reduced job satisfaction. The aim of this study is to detect the differences in job satisfaction of employees in manufacturing sector and education. It is expected that the research results will provide a better insight into and the understanding of the situation in this area. Therefore, the research highlights the elements which contribute to reduced job satisfaction in general, and especially in industrial sector and education. On the basis of these findings, it is possible to define appropriate actions, in order to increase job satisfaction. Given the importance of job satisfaction, both in manufacturing sector and in education, this will lead to improved business performance and other organizational outcomes.

The results of two surveys, conducted back in 2011 and 2013 in Serbia, were used to perform the desired conclusion. The first survey was conducted in Serbian companies. Among other things, 
this survey determined the impacts of organizational culture on job satisfaction (Vukonjanski et al., 2012), satisfaction with communication on job satisfaction (Nikolić et al., 2013), as well as the relationship between leadership and leader - member exchange (LMX theory) (Nikolić et al., 2012). Another survey was carried out in primary schools in Serbia. This paper presents the results of these two surveys, which are related to job satisfaction of men and women in manufacturing sector and education in Serbia.

\section{PROBLEM}

There are numerous definitions of job satisfaction. Locke (1976) defines job satisfaction as a pleasurable or positive emotional state, resulting from the appraisal of one's job or job experiences. According to Spector (1997), job satisfaction is a person's evaluation of his (or her) job and work context, i.e. an attitude reflecting how much people like or dislike their job.

Job satisfaction is more an attitude than behavior (Robins and Coulter, 2005). However, the consequences of that attitude have an influence on behaviour: satisfied employees come to work regularly, they work better, achieve better work performance and they are loyal to their organization (Robins and Coulter, 2005). It was found that job satisfaction can contribute to the psychological stability of employees, both in and outside the workplace (Robbins et al., 2003). Job satisfaction of employees affects their physical and mental health, longevity and emotional life in general (Locke, 1976; Sempane et al., 2002).

\section{METHOD}

\section{Survey instrument}

The Job Satisfaction Survey questionnaire (Spector, 1985) was used as an instrument for measuring job satisfaction. This questionnaire has 36 items, related to nine dimensions of job satisfaction. The answers are measured by a 6-point Likert scale. Dimensions of job satisfaction are defined and described in the following way (Spector, 1985): JS1 - Pay (Pay and remuneration), JS2 - Promotion (Promotion opportunities), JS3 - Supervision (Immediate supervisor), JS4 - Fringe Benefits (Monetary and nonmonetary fringe benefits), JS5 - Contingent Rewards (Appreciation, recognition, and rewards for good work), JS6 - Operating Procedures (Operating policies and procedures), JS7 - Co-workers (People you work with), JS8 - Nature of Work (Job tasks themselves), JS9 - Communication (Communication within the organization).

The Job Satisfaction Survey questionnaire is customarily used to measure job satisfaction in companies, therefore, in industrial sector. However, this form can be used to measure the satisfaction of employees in education, such as in reference (Astrauskaite et al., 2011). Using the same questionnaire to measure job satisfaction of employees in manufacturing sector and education, was, certainly helpful for the analysing the results in this paper. In this way, it provides a high degree of comparability of the results.

\section{Participants and data collection}

The survey in industrial sector included companies in Serbia. The data was obtained by questioning $\mathrm{N} 1=256$ middle managers, from 131 companies. All examined managers have higher education. In the sample of $\mathrm{N} 1=256$ respondents, there were 136 men and 120 women. This survey was carried out in 2011.

The survey in education included primary schools in Serbia, from the fifth to eighth grade. The data was obtained by questioning N2 = 362 teachers, from 57 primary schools. All examined teachers have higher education. In the sample of $\mathrm{N} 2=362$ respondents, there were 250 men and 112 women. This survey was carried out in 2013.

\section{RESULTS}

In the survey that was conducted in industrial sector, the values of Cronbach's Alpha, for all dimensions of job satisfaction, range from $\alpha=0.703$ to $\alpha=0.834$. In the survey that was conducted in education, the values of Cronbach's Alpha, for all dimensions of job satisfaction, range from $\alpha=0.703$ do $\alpha=0.870$.

Table 1 shows the comparative results of the average values of all nine dimensions of job satisfaction in manufacturing sector and education. T-test (independent samples test) was used for the comparison of two sets of data (job satisfaction in industrial sector and job satisfaction in education). The main results of statistical analysis are also given in Table 1. It can be noted that, in five dimensions (JS3, JS5, JS7, JS8 and JS9), there is a statistically 
Group Statistics

\begin{tabular}{|c|c|c|c|c|c|c|c|c|c|c|c|}
\hline \multicolumn{2}{|c|}{$\begin{array}{l}\text { Industry and Edu- } \\
\text { cation }\end{array}$} & \multirow{2}{*}{$\begin{array}{c}N \\
256\end{array}$} & \multirow{2}{*}{$\begin{array}{c}\text { Mean } \\
2.9107\end{array}$} & \multirow{2}{*}{$\begin{array}{c}\begin{array}{c}\text { Std. Devia- } \\
\text { tion }\end{array} \\
1.32451 \\
\end{array}$} & \multirow{2}{*}{$\begin{array}{c}\begin{array}{c}\text { Std. Error } \\
\text { Mean }\end{array} \\
.08850\end{array}$} & \multirow[t]{2}{*}{$\mathrm{F}$} & \multirow[t]{2}{*}{ Sig. } & \multirow{2}{*}{$\frac{t}{-1.627}$} & \multirow{2}{*}{$\begin{array}{c}\mathrm{df} \\
584\end{array}$} & \multirow{2}{*}{$\begin{array}{c}\begin{array}{c}\text { Sig. } \\
\text { (2-tailed) }\end{array} \\
.104\end{array}$} & \multirow{2}{*}{$\begin{array}{c}\begin{array}{c}\text { Mean Differ } \\
\text { ence }\end{array} \\
-.16042\end{array}$} \\
\hline IS1 & Industry & & & & & & & & & & \\
\hline 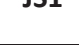 & Education & 362 & 3.0711 & 1.04518 & .05493 & 24.063 & .000 & -1.540 & 392.005 & .124 & -.16042 \\
\hline \multirow{2}{*}{ JS2 } & Industry & 256 & 3.3304 & 1.18838 & .07940 & & & -1.304 & 584 & .193 & -.14064 \\
\hline & Education & 362 & 3.4710 & 1.31547 & .06914 & 6.872 & .009 & -1.336 & 508.709 & .182 & -.14064 \\
\hline \multirow{2}{*}{ JS3 } & Industry & 256 & 3.6641 & 1.29293 & .08639 & & & -10.042 & 584 & .000 & -1.02655 \\
\hline & Education & 362 & 4.6906 & 1.14312 & .06008 & 6.969 & .009 & -9.756 & 428.911 & .000 & -1.02655 \\
\hline \multirow{2}{*}{ JS4 } & Industry & 256 & 2.9989 & 1.25291 & .08371 & & & .398 & 584 & .690 & .04446 \\
\hline & Education & 362 & 2.9544 & 1.34867 & .07088 & 3.590 & .059 & .405 & 498.963 & .685 & .04446 \\
\hline \multirow{2}{*}{ JS5 } & Industry & 256 & 3.1529 & 1.35047 & .09023 & & & -3.779 & 584 & .000 & -.42237 \\
\hline & Education & 362 & 3.5753 & 1.29203 & .06791 & .002 & .964 & -3.740 & 456.655 & .000 & -.42237 \\
\hline \multirow{2}{*}{ JS6 } & Industry & 256 & 3.1830 & 1.04199 & .06962 & & & -.311 & 584 & .756 & -.02760 \\
\hline & Education & 362 & 3.2106 & 1.04305 & .05482 & .558 & .455 & -.311 & 472.953 & .756 & -.02760 \\
\hline \multirow{2}{*}{ JS7 } & Industry & 256 & 4.3571 & 1.13777 & .07602 & & & -2.788 & 584 & .005 & -.24092 \\
\hline & Education & 362 & 4.5981 & .93377 & .04908 & 7.049 & .008 & -2.663 & 404.246 & .008 & -.24092 \\
\hline \multirow{2}{*}{ JS8 } & Industry & 256 & 4.4900 & 1.23553 & .08255 & & & -9.009 & 584 & .000 & -.77662 \\
\hline & Education & 362 & 5.2666 & .84890 & .04462 & 36.174 & .000 & -8.276 & 353.670 & .000 & -.77662 \\
\hline \multirow[t]{2}{*}{ JS9 } & Industry & 256 & 3.9699 & 1.31775 & .08805 & & & -8.936 & 584 & .000 & -.83953 \\
\hline & Education & 362 & 4.8094 & .95043 & .04995 & 44.050 & .000 & -8.293 & 366.230 & .000 & -.83953 \\
\hline
\end{tabular}

Table 1. Comparative result of the average values of all nine dimensions of job satisfaction in manufacturing sector and education (t-test)
Independent Samples Test

\begin{tabular}{|c|c|c|c|c|c|c|c|c|c|c|c|}
\hline \multicolumn{2}{|c|}{ Industry } & $\mathrm{N}$ & Mean & $\begin{array}{l}\text { Std. Devia- } \\
\text { tion }\end{array}$ & $\begin{array}{l}\text { Std. Error } \\
\text { Mean }\end{array}$ & $F$ & Sig. & $\mathrm{t}$ & $d f$ & $\begin{array}{c}\text { Sig. } \\
\text { (2-tailed) }\end{array}$ & $\begin{array}{l}\text { Mean Dif- } \\
\text { ference }\end{array}$ \\
\hline \multirow{2}{*}{ JS1 } & Men & 136 & 3.1766 & 1.36458 & .12157 & & & 3.491 & 222 & .001 & 60771 \\
\hline & Women & 120 & 2.5689 & 1.19318 & .12053 & 3.965 & .048 & 3.550 & 218.925 & .000 & .60771 \\
\hline \multirow{2}{*}{ JS2 } & Men & 136 & 3.4881 & 1.24413 & .11084 & & & 2.274 & 222 & .024 & .36054 \\
\hline & Women & 120 & 3.1276 & 1.08543 & .10964 & 4.449 & .036 & 2.313 & 219.040 & .022 & .36054 \\
\hline \multirow{2}{*}{ JS3 } & Men & 136 & 3.7718 & 1.38925 & .12376 & & & 1.418 & 222 & .158 & .24632 \\
\hline & Women & 120 & 3.5255 & 1.14957 & .11612 & 8.824 & .003 & 1.451 & 221.123 & .148 & .24632 \\
\hline \multirow{2}{*}{ JS4 } & Men & 136 & 3.1508 & 1.31304 & .11698 & & & 2.073 & 222 & .039 & .34722 \\
\hline & Women & 120 & 2.8036 & 1.14831 & .11600 & 3.027 & .083 & 2.108 & 218.917 & .036 & .34722 \\
\hline \multirow{2}{*}{ JS5 } & Men & 136 & 3.4345 & 1.42695 & .12712 & & & 3.635 & 222 & .000 & .64371 \\
\hline & Women & 120 & 2.7908 & 1.15472 & .11664 & 7.249 & .008 & 3.731 & 221.634 & .000 & .64371 \\
\hline \multirow{2}{*}{ JS6 } & Men & 136 & 3.2837 & 1.04850 & .09341 & & & 1.646 & 222 & .101 & .23016 \\
\hline & Women & 120 & 3.0536 & 1.02435 & .10347 & .136 & .713 & 1.651 & 210.850 & .100 & .23016 \\
\hline \multirow{2}{*}{ JS7 } & Men & 136 & 4.4603 & 1.08001 & .09621 & & & 1.544 & 222 & .124 & .23583 \\
\hline & Women & 120 & 4.2245 & 1.20056 & .12128 & .439 & .508 & 1.523 & 196.979 & .129 & .23583 \\
\hline \multirow{2}{*}{ JS8 } & Men & 136 & 4.6905 & 1.23306 & .10985 & & & 2.796 & 222 & .006 & .45833 \\
\hline & Women & 120 & 4.2321 & 1.19613 & .12083 & .358 & .550 & 2.807 & 211.494 & .005 & .45833 \\
\hline \multirow[t]{2}{*}{ JS9 } & Men & 136 & 4.0020 & 1.36033 & .12119 & & & .413 & 222 & .680 & .07341 \\
\hline & Women & 120 & 3.9286 & 1.26664 & .12795 & .026 & .873 & .417 & 214.896 & .677 & .07341 \\
\hline
\end{tabular}

Table 2. Comparative results of the average values of all nine dimensions of job satisfaction of men and women in industrial sector (t-test) 
Independent Samples Test

\begin{tabular}{|c|c|c|c|c|c|c|c|c|c|c|c|}
\hline \multicolumn{2}{|c|}{ Education } & $N$ & Mean & $\begin{array}{l}\text { Std. Devia- } \\
\text { tion }\end{array}$ & $\begin{array}{c}\text { Std. Error } \\
\text { Mean }\end{array}$ & $F$ & Sig. & $\mathrm{t}$ & $d f$ & $\begin{array}{c}\text { Sig. } \\
\text { (2-tailed) }\end{array}$ & $\begin{array}{l}\text { Mean Differ- } \\
\text { ence }\end{array}$ \\
\hline \multirow{2}{*}{ JS1 } & Men & 112 & 3.1092 & 1.07299 & .12734 & & & .341 & 360 & .733 & .04730 \\
\hline & Women & 250 & 3.0619 & 1.03995 & .06096 & .337 & .562 & .335 & 104.440 & .738 & .04730 \\
\hline \multirow{2}{*}{ JS2 } & Men & 112 & 3.3873 & 1.31664 & .15626 & & & -.597 & 360 & .551 & -.10408 \\
\hline & Women & 250 & 3.4914 & 1.31664 & .07718 & .097 & .756 & -.597 & 106.791 & .552 & -.10408 \\
\hline \multirow{2}{*}{ JS3 } & Men & 112 & 4.4225 & 1.13593 & .13481 & & & -2.216 & 360 & .027 & -.33348 \\
\hline & Women & 250 & 4.7560 & 1.13723 & .06667 & .000 & .983 & -2.217 & 106.879 & .029 & -.33348 \\
\hline \multirow{2}{*}{ JS4 } & Men & 112 & 3.0951 & 1.32582 & .15735 & & & .980 & 360 & .328 & .17497 \\
\hline & Women & 250 & 2.9201 & 1.35421 & .07939 & .019 & .889 & .993 & 108.476 & .323 & .17497 \\
\hline \multirow{2}{*}{ JS5 } & Men & 112 & 3.6021 & 1.30629 & .15503 & & & .195 & 360 & .846 & .03338 \\
\hline & Women & 250 & 3.5687 & 1.29072 & .07566 & .001 & .973 & .194 & 105.870 & .847 & .03338 \\
\hline \multirow{2}{*}{ JS6 } & Men & 112 & 3.3310 & .98178 & .11652 & & & 1.085 & 360 & .279 & .14971 \\
\hline & Women & 250 & 3.1813 & 1.05700 & .06196 & .778 & .378 & 1.134 & 113.010 & .259 & .14971 \\
\hline \multirow{2}{*}{ JS7 } & Men & 112 & 4.5810 & .94281 & .11189 & & & -.172 & 360 & .864 & -.02125 \\
\hline & Women & 250 & 4.6022 & .93315 & .05470 & .379 & .539 & -.171 & 105.999 & .865 & -.02125 \\
\hline \multirow{2}{*}{ JS8 } & Men & 112 & 5.0141 & .97458 & .11566 & & & -2.822 & 360 & .005 & -.31409 \\
\hline & Women & 250 & 5.3282 & .80523 & .04720 & 7.018 & .008 & -2.514 & 94.627 & .014 & -.31409 \\
\hline \multirow[t]{2}{*}{ JS9 } & Men & 112 & 4.7183 & 1.00706 & .11952 & & & -.900 & 360 & .369 & -.11331 \\
\hline & Women & 250 & 4.8316 & .93656 & .05490 & 1.251 & .264 & -.861 & 101.569 & .391 & -.11331 \\
\hline
\end{tabular}

Table 3. Comparative results of the average values of all nine dimensions of job satisfaction of men and women in education (t-test)

significant difference between the observed groups of data. The results of these five dimensions are marked in Table 1.

Table 2 shows the comparative results of the average values of all nine dimensions of job satisfaction of men and women in manufacturing sector. T-test (independent samples test) was used for the comparison of two sets of data (job satisfaction of men in industrial sector and job satisfaction of women in industrial sector). The main results of statistical analysis are also given in Table 2. It can be noted that, in five dimensions (JS1, JS2, JS4, JS5 and JS9), there is a statistically significant difference between the observed groups of data. The results of these five dimensions are marked in Table 2.

Table 3 shows the comparative results of the average values of all nine dimensions of job satisfaction of men and women in education. T-test (independent samples test) was used for the comparison of two sets of data (job satisfaction of men in education and job satisfaction of women in education). The main results of statistical analysis are also given in Table 3. It can be noted that, in two dimensions (JS3 and JS8), there is a statistically significant difference between the observed groups of data. The results of these two dimensions are marked in Table 3.

\section{DISCUSSION}

Based on the results obtained by t- test, presented in Table 1, we can see that in five (of nine) dimensions of job satisfaction, there are significant statistical gaps between job satisfaction, among employees in manufacturing sector and education. This, overall analysis was done without taking into account the gender of respondents.

Differences in job satisfaction in industrial sector and education were found in the following dimensions: JS3 - Supervision, JS5 - Contingent Rewards, JS7 - Co-workers, JS8 - Nature of Work, JS9 - Communication. In all five cases, the job satisfaction of employees is higher in education than in manufacturing sector. This can be seen from the average values of the observed dimensions of job satisfaction in manufacturing sector and education. Looking at the average marks, the results for both groups are around the average, but still higher at teachers than at those employed in enterprises.

Striking of employees in the education sector (mainly because of low wages) has been common in Serbia in recent decades. Therefore, an opinion has been formed in the public that teachers are dissatisfied with their job. This view arose, because the 
dissatisfaction with salary is often equated with the overall job dissatisfaction. The results, however, indicate that salary is not crucial for the perception of job satisfaction among teachers. Also, employees in education are becoming aware that their position is not really that bad, compared to the employees in industrial sector, primarily due to the shorter working hours, greater number of free days, and regular and secure incomes.

Possible explanations for each dimension separately follow:

- JS3 - Supervision. In primary schools, like in public institutions, there is less uncertainty in the process of governance and management. In this regard, the directors of the schools are under less pressure from the leaders in manufacturing sector. Consequently, employees in industrial sector feel more pressure from the management, and this results in a decline of satisfaction with supervision.

- JS5 - Prizes in education are generally not of material character; they are usually given in the form of certain recognitions and accolades. For example, when a teacher has a successful mentoring and his student wins a prize in national and international competitions, it is difficult to pass without a proper acknowledgment, praise, promotion within the school and local community, and sometimes beyond. For teacher, there is a satisfaction with these and similar successes, as well as a feeling that additional efforts and successes are adequately evaluated. Teachers in such activities do not expect financial compensation. On the other hand, the employees in industrial sector expect financial compensation for any overtime, extra work and achievements. However, in the companies in Serbia, all of the above mentioned is often not accompanied by appropriate rewards. The reasons for this are poor financial strength of a large number of companies, negligence of the management and high labor force fluctuation, due to the high percentage of unemployed. Because of all this, it happens that rewards for the employees in manufacturing sector are often absent, although employees deserve them, and this leads to lower satisfaction in this area.

- JS7 - Co-workers. In education, the teachers are not so much directed at each other, since they each teach their courses and do not have many of common activities. If there are joint activities (clubs, excursions/school trips, competitions), teachers are in a better position to choose their associates, while in industrial sector this is often not possible. The conclusion is that in education there are fewer potentially adverse situations, that may lead to dissatisfaction, than in industrial sector.

- JS8 - Nature of Work. The job in education may not be paid as certain jobs in manufacturing sector (although it depends on the particular company and many other factors), but carries less uncertainty and stress. Also a job in education means more free time, and summer and winter holidays. A potential problem, in the nature of work in the education sector, is the need to work with children, but people who have problem with this, usually do not start their career as teachers. (This does not mean that work in education is relatively easy, stress-free and free of responsibilities: stress and responsibility exist, but they are not concentrated on a certain amount of activity and a period of time. Errors in the economy can be immediately noticed, the consequences come much faster, and it is known who is responsible for most situations. For example, if a manufacturing process error occurs, because of a technologist's mistake, it can endanger the health of consumers and / or employees; it can go with the withdrawal of entire series of products from the market, big losses for the company etc. On the other hand, if a teacher performs his job badly, such situation can last for years, and the effects will be visible in a few decades, when it will be difficult to identify the cause and the culprit. So in education responsibility is rather fuzzy and undefined, with no clear consequences for those who make a mistake.)

- JS9 - Communication. In this case, similar explanations can be accepted to those given in dimensions JS7 - Associates. Teachers, to a greater extent, can choose with whom they want to communicate. For example, if a math teacher does not want to communicate with a biology teacher, he can, actually, largely avoid the communication, and this does not, in any way, affect the work of either teacher.

Based on the results obtained by t-test, presented in Table 2, we can see that in five (of nine) dimensions of job satisfaction, there are significant gaps between job satisfaction among women in indus- 
trial sector and the job satisfaction of women in the economy. Difference exists in the following sizes: JS1 - Pay, JS2 - Promotion, JS4 - Fringe Benefits, JS5 - Contingent Rewards, JS8 - Nature of Work. In all the five cases, job satisfaction in industrial sector is higher at men than at women. This can be seen from the average values of the observed dimensions of job satisfaction between men and women in the manufacturing sector. Thus, at most dimensions of job satisfaction in industrial sector, men are more satisfied with their work.

A significant number of references examine the differences in job satisfaction between men and women. The results vary in a wide range. Some pieces of research suggest that there are differences in job satisfaction between men and women (Bokemeier and Lacy, 1987; Choi, 2013). The largest number of studies, for example (D'Arcy et al., 1984; Groot and Maassen van den Brink, 2000), shows that women are more satisfied with their job than man. This is generally interpreted in the way that women have less ambitions and expectations, in the business sphere, than man. On the other hand, a small amount of research shows that men are more satisfied with their job than women (Jung et al., 2007; Chiu, 1998; Lindorff, 2011). This result is obtained in this paper. In this case, for the conditions in Serbia, this can be explained by a significant margin results for the dimension of organizational culture - gender egalitarianism, between the actual state and the state how it should be (Vukonjanski et al., 2012). Unfortunately, in manufacturing sector women are not completely equal with men, and this is reflected in the fact that men are more encouraged to professional development than women; fewer women are in authoritative positions. This situation leads to the decreased job satisfaction among women in industrial sector.

In addition, for an explanation of this situation, it is necessary to consider the particular dimension which, apparently, is the key in this case, and this is the dimension JS8 - Nature of Work. The Nature of the work in manufacturing sector is such that it often requires full-time working hours, often working long hours, working on weekends, holidays. In addition, in industrial sector there are more changes that require additional work, further learning, and that brings a new loss of time and additional stress. This is especially true for women who, in such circumstances, usually sacrifice their careers and their work, to a greater extent, because of taking care of their family. The logical consequence is that men tend to have an advantage in manufacturing sec- tor; they progress faster in their job, given that, in most cases, they have more time for business and career. As a result, men are often better able to be paid more, to get a promotion, additional privileges and be rewarded. Therefore, men are more satisfied, with the nature of the work in industrial sector, and other dimensions, as listed above.

Based on the results obtained by t-test, shown in Table 3, we can see that in two (of nine) dimensions of job satisfaction, there was a statistically significant gap between job satisfaction among men in education and job satisfaction of women in education. Differences exist in the following sizes: JS3 -Supervision, JS8 - Nature of Work. In both cases, job satisfaction in education is higher at women than at men. This can be seen from the average values of the observed dimensions of job satisfaction between men and women in education. Given that, at a small number of dimensions of job satisfaction, there is a greater job satisfaction of women than men in education.

These results have some similarities with the results of the research in Cyprus, where it was determined that the gender of the teacher has no effect on his/her job satisfaction (Eliophotou Menon and Athanasoula-Reppa, 2011). However, the results, obtained in this study, are also consistent with the studies that confirm that women are more satisfied with a job in education (Ladebo, 2005; Ghazi and Maringe, 2011).

In education there is a balance between job satisfaction between men and women. While there are five statistically significant differences of job satisfaction in manufacturing sector, such differences in education occur only in the two dimensions of job satisfaction. As it was expected, women are more satisfied with the nature of the work in education. Women employed in the education sector feel accomplished by their professional work; they are doing a respectable job, have more time for their family and do not feel they should contribute financially more to the family. In addition, women are more satisfied with the dimension JS3 - Supervision. A possible explanation is that men in education are following the work of the school principal, because they are more interested in some of the organizational and managerial aspects of the school, and therefore, they have the opportunity to spot a situation with which they are not satisfied. At the same time, women in education, simply because they are satisfied with the nature of their work, pay less attention to the work of the principal and supervision. 


\section{CONCLUSION}

Having conducted the analysis, we can conclude the following: employee job satisfaction is higher in education than in manufacturing sector; job satisfaction in industrial sector is higher at men than at women; job satisfaction in education is slightly higher at women than at men. In all the three analyses, there is only one dimension of job satisfaction, in which there are still significant differences: JS8 - Nature of Work. The impression is that this dimension plays a key role in understanding the results. Satisfaction or dissatisfaction with the nature of the work indirectly reflects on some dimensions of job satisfaction, both in industrial sector and in education. Women are more satisfied with the nature of work in education, while men are more satisfied with the nature of work in manufacturing sector. When it comes to the overall analysis, the job satisfaction is greater in education, than in manufacturing sector. This can also be explained by the nature of the work in education as, in general, this job brings more free time, with less stress, changes and uncertainty. The results may have significance for the theory and practice of management in Serbian enterprises and schools. Based on these results, managers can better understand their employees and take appropriate actions, in order to increase job satisfaction. This will have a positive impact on business performances and the effectiveness of enterprises and schools.

\section{REFERENCES}

Astrauskaite, M., Vaitkevicius, R., \& Perminas, A. (2011). Job satisfaction survey: A confirmatory factor analysis based on secondary school teachers' sample. International Journal of Business and Management, 6(5), 41-51.

Bellou, V. (2010). Organizational culture as a predictor of job satisfaction: The role of gender and age. Career Development International, 15(1), 4-19. doi: 10.1108/13620431011020862.

Bokemeier, J.L., \& Lacy, W.B. (1987). Job values, rewards, and work conditions as factors in job satisfaction among men and women. The Sociological Quarterly, 28, 189-204. doi: 10.1111/j.1533-8525.1987.tb00290.x.

Chiu, C. (1998). Do professional women have lower job satisfaction than professional men? Lawyers as a case study. Sex Roles, 38(7-8), 521-537. doi: 10.1023/A:1018722208646.

Choi, S. (2013). Demographic diversity of managers and employee job satisfaction empirical analysis of the federal case. Review of Public Personnel Administration, 33(3), 275-298. doi: 10.1177/0734371X12453054.
D’Arcy, C., Syrotuik, J., \& Siddique, C.M. (1984). Perceived job attributes, job satisfaction, and psychological distress: A comparison of working men and women. Human Relations, 37(8), 603-61. doi: 10.1177/001872678403700803.

Eliophotou Menon, M., \& Athanasoula-Reppa, A. (2011). Job satisfaction among secondary school teachers: The role of gender and experience. School Leadership \& Management, 31(5), 435-450. doi: 10.1080/13632434.2011.614942.

Fargher, S., Kesting, S., Lange, T., \& Pacheco, G. (2008). Cultural heritage and job satisfaction in Eastern and Western Europe. International Journal of Manpower, 29, 630-650. doi: 10.1108/01437720810908938.

Fraser, J., \& Hodge, M. (2000). Job satisfaction in higher education: Examining gender in professional work settings. Sociological Inquiry, 70(2), 172-178. doi: 10.1111/j.1475-682X.2000.tb00904.x.

Ghazi, S.R., \& Maringe, F. (2011). Age, gender and job satisfaction among elementary school head teachers in Pakistan. Education, Knowledge and Economy, 5(12), 17-27.

Groot, W., \& Maassen van den Brink, H. (2000). Job satisfaction, wages and allocation of men and women, advances in quality of life theory and research. Social Indicators Research Series, 4, 111-128. doi: 10.1007/978-94-011-4291-5_6.

Ho C.L., \& Au, W.T. (2006). Teaching satisfaction scale: Measuring job satisfaction of teachers. Educational and Psychological Measurement, 66(1), 172-185. doi: 10.1177/0013164405278573.

Hoerr, T.R. (2013). Principal connection: Is your school happy? Educational Leadership, 70(8), 86-87.

Judge, T.A., Thoresen, C.J., Bono, J.E., \& Patton, G.K. (2001). The job satisfaction - job performance relationship: A qualitative and quantitative review. Psychological Bulletin, 127, 376-407. doi: 10.1037//00332909.I27.3.376.

Jung, K., Moon, M.J., \& Deuk Hahm, S. (2007). Do age, gender, and sector affect job satisfaction? Results from the Korean labor and income panel data. Review of Public Personnel Administration, 27(2), 125-146. doi: 10.1177/0734371X06289229.

Ladebo, O.J. (2005). Effects of work-related attitudes on the intention to leave the profession: An examination of school teachers in Nigeria. Educational Management Administration \& Leadership, 33(3),355-369. doi: 10.1177/1741143205054014.

Lee, Y.D., \& Chang, H.M. (2008). Relations between team work and innovation in organisations and the job satisfaction of employees: A factor analytic study. International Journal of Management, 25(4), 732-779.

Lindorff, M. (2011). Job satisfaction and gender in the APS: Who'd want to be a male? Australian Journal of Public Administration, 70(1), 58-74. doi: 10.1111/j.14678500.2010.00707.x. 
Locke, E.A. (1976). The nature and causes of job satisfaction. In M.D. Dunnette (Ed.), Handbook of industrial and organizational psychology. Chicago: Rand McNally.

Locke, E.A., \& Latham, G.P. (1990). Work motivation and satisfaction - light at the end of the tunnel. Psychological Science, 1(4), 240-246. doi: 10.1111/j.1467-9280.1990. tb00207.x.

McCormick, E.J., \& Ilgen, D.R. (1985). Industrial and organisational psychology (8th ed.). London: Allen \& Unwin.

Megginson, L.C., Mosley, D.C., \& Pietri, P.H. (1982). Management concepts and applications (4th ed.). New York: Harper Collins.

Meyer, J.P., Stanley, D.J., Herscovitch, L., \& Topolnytsky, L. (2002). Affective, continuance and normative commitment to the organization: A meta-analysis of antecedents, correlates, and consequences. Journal of Vocational Behavior, 61, 20-52.

Nikolić, M., Vukonjanski, J., \& Terek, E. (2012). Stanje liderstva i LMX u preduzećima u Srbiji. Tehnika, 67(2), 287291. (in Serbian).

Nikolić, M., Vukonjanski, J., Nedeljković, M. Hadžić, O., \& Terek, E. (2013). The impact of internal communication satisfaction dimensions on job satisfaction dimensions and the moderating role of LMX. Public Relations Review, 39(2013), 563-565. doi: 10.1016/j.pubrev.2013.09.002.

Robbins, M.J., Peterson, M., Tedrick, T., \& Carpenter, J.R. (2003). Job satisfaction on NCAA Division III athletic directions: Impact on job design and time on task. International Sports Journal, 7(2), 46-57.
Robins, S., \& Coulter, M. (2005). Menadžment. Beograd: Data Status. (in Serbian).

Scott, D., \& Taylor, G.S. (1985). An examination of conflicting findings between job satisfaction and absenteeism: A meta analysis. Academy of Management Journal, 28, 599-612.

Sempane, M.E., Rieger, H.S., \& Roodt, G. (2002). Job satisfaction in relation to organisational culture. SA Journal of Industrial Psychology, 28(2), 23-30. doi: 10.4102/ sajip.v28i2.49.

Shann, M.H. (1998). Professional commitment and satisfaction among teachers in urban middle schools. The Journal of Educational Research, 92(2), 67-73.

Spector, P.E. (1985). Measurement of human service staff satisfaction: Development of the job satisfaction survey. American Journal of Community Psychology, 13(6), 693-713.

Spector, P.E. (1997). Job satisfaction: Application, assessment, cause, and consequences. Thousand Oaks, CA: Sage Publications.

Vukonjanski, J., Nikolić, M., Hadžić, O., Terek, E., \& Nedeljković, M. (2012). Relationship between GLOBE organizational culture dimensions, job satisfaction and leader-member exchange in Serbian organizations. Journal for East European Management Studies, 17(3), 333-368.

Wolk, S. (2008). Joy in school. Educational Leadership, 66(1), 8-15.

\section{ZADOVOLJSTVO POSLOM MUŠKARCA I ŽENA ZAPOSLENIH U PRIVREDI I OBRAZOVANJU U SRBIJI}

\section{Rezime:}

Ovaj rad predstavlja rezultate istraživanja, na temu zadovoljstva poslom muškaraca i žena zaposlenih u privredi i obrazovanju u Srbiji. Istraživanja su sprovedena u srpskim preduzećima i osnovnim školama. U prvom istraživanju, podaci su dobijeni ispitivanjem N1 = 256 menadžera na srednjem nivou, iz 131 kompanije u Srbiji. Uzorak je sačinjen od 136 muškaraca i 120 žena. U drugom istraživanju, podaci su dobijeni ispitivanjem N2 = 362 nastavna radnika, iz 57 osnovnih škola u Srbiji. Ovaj uzorak sastojao se od 250 žena i 112 muškaraca. T-test je upotrebljen za statističku analizu. Tačnije, tri t-testa su upotrebljena za sledeće grupe podataka: zadovoljstvo poslom u privredi i zadovoljstvo poslom u obrazovanju; zadovoljstvo poslom muškaraca u privredi i zadovoljstvo poslom žena u privredi; zadovoljstvo poslom muškaraca u obrazovanju i zadovoljstvo poslom žena u obrazovanju. Najvažniji zaključci, do kojih smo došli, su sledeći: zadovoljstvo poslom je veće u obrazovanju nego u privredi; zadovoljstvo poslom u privredi je veće kod muškaraca nego kod žena; zadovoljstvo poslom u obrazovanju je nešto veće kod žena nego kod muškaraca.

\author{
Ključne reči: \\ zadovoljstvo poslom, \\ muškarci, žene, \\ kompanije u Srbiji, \\ osnovne škole u Srbiji.
}

Received: November 19th, 2013. Correction: November 23rd, 2013. Accepted: December 5th, 2013. 